DOI: https://doi.org/10.31992/0869-3617-2020-29-6-75-82

\title{
Sustainable Development Principles for Engineering Educator
}

Jose C.Quadrado - PhD, DSc, Prof., Vice-president, e-mail: jcquadrado@gmail.com

Instituto Politécnico do Porto, Portugal

Address: Rua Dr. Roberto Frias 4200-465 Porto, Portugal

Mansur F. Galikhanov - Dr. Sci. (Engineering), Prof., Director of the Institute of Additional Professional Education, e-mail:mgalikhanov@yandex.ru

Kazan National Research Technological University, Tatarstan, Russia

Address: 68, K. Marx str., Kazan, 420015, Russian Federation

Kseniya K.Zaitseva - Cand. Sci. (Education), Assoc. Prof., e-mail: kkzaitseva@gmail.com

Tomsk Polytechnic University, Tomsk, Russia

Address: 30, Lenin Ave., Tomsk, 634050, Russian Federation

Abstract. This paper focuses on the justification and incorporation of sustainable development course into the certified training of engineering educators.

Under the ERASMUS+ Project ENTER, a consortium was set up to build the capacity of engineering HEIs by strengthening engineering educators' preparation by an innovative kind of engineering pedagogy. One of the project tasks is to create a novel multicultural and international approach for formal post-graduate professional and pedagogical education of engineering educators.

After a thorough educational market analysis, study of HEIs requirements and educators' needs, a formal training program was designed. One of the core courses of that program is the course on Sustainable Development. The main aim of this course is to help educators to develop a strategy how to integrate sustainable development principles into engineering education at large.

Keywords: engineering educators, professional development training, sustainable development in engineering education

Cite as: Quadrado, J.C., Galikhanov, M.F., Zaitseva, K.K. (2020). Sustainable Development Principles for Engineering Educator. Vysshee obrazovanie v Rossii = Higher Education in Russia. Vol. 29, no. 6, pp. 75-82.

DOI: https://doi.org/10.31992/0869-3617-2020-29-6-75-82

\section{Introduction}

The ERASMUS+ ENTER (EngineeriNg educaTors $\mathrm{pEdagogical}$ tRaining $)^{1}$ project was set up by a consortium of HEI's and Accreditation Agencies from Europe, Russia, and Kazakhstan. The main idea of the ENTER project is to build the capacity of engineering HEIs due to the strengthening of engineering educators' prepa-

${ }^{1}$ ENTER Project official website. Available at: http://erasmus-enter.org ration with innovative engineering pedagogy. Because of this particular sort of educator's concerns to such a specific field that has a high impact on scientific progress and innovative development of humanity it is very important how the teaching and learning processes are organized and what is the content and teaching methodology. That has a great impact on the potential quality of learning outcomes of future engineers and consequently on the industry and economic development. 
The innovations of the 3-tiered training programs (i-PET programs) meet the needs of the engineering educator's pedagogical development. It is intended that ENTER outputs and outcomes innovations will concern to:

Content. The 21st century Engineering HEI Teacher must be some kind of coach with very strong psychological, sociological and methodological basic competences [1]. But now traditional engineering pedagogy content like delivered by IGIP has to be upgraded to meet modern society demands. Engineering Teachers have to be collaborative problem-solvers themselves and lifelong learners (be willing to learn always). Novelty skills, which they need are: ethical skills, cross-cultural communication, psychological sustainability under the stress factors of the modern environment, marketing and management skills, including their e-formats. Also, the social networking, ICT literacy, found raising and financial accounting, linguistic skills, methods of productivity meaning ability to writing worldclass reports, articles, teaching materials, and guides make part of engineering educator's needs list. Such as an MBA for Engineering teachers.

Methodology. Another innovative aspect of iPET content and methodology is a series of subjects dealing with the development of creativity: TRIZ-methodology, mind-mapping, and such evergreen creativity conducting as brainstorming, case study, and business games and different sorts of training.

Ways of pedagogical teaching and learning outcome delivery. Some kind of blended-learning integrated off-line and on-line facility using advanced networking systems also in on-line and off-line formats as a powerful means in partner countries are considered. The main objective of the Consortium is to develop a multi-level modular system for pedagogical training of engineering educators based on international network cooperation.

According to the ENTER Case Analysis Survey $^{2}$ data, the following common aspects influ-

${ }^{2}$ Enter Project deliverable: Best practices of pedagogical education for engineering teachers. Avail- encing the state of engineering educators' pedagogical training in Kazakhstan and Russia may be highlighted:

- globalization of knowledge based on the Internet. Formation of a global market of educational services;

- development of e-learning tools for distance learning and mixed technologies;

- narrow specialization of engineering universities' graduates;

- growth of the high technology component of production processes, robotization, and digitalization of processes and equipment;

- non-formal education recognition, that complements formal institutional education;

- the sectoral orientation of the universities related to the structure of the productive sector of the industrial society.

The need to improve pedagogical training of engineering educators to prepare highly qualified engineering personnel is consistent with national priorities of the modernization of education both in Kazakhstan and Russia and can be traced in the regulatory documents of these countries.

\section{Importance of Sustainable Development in Engineering Education}

Back in 2002, at the World Summit on Sustainable Development (WSSD) in Johannesburg $^{3}$, the idea was expressed that it is an insufficient level of education and public awareness on sustainable development (SD) that can cause problems in the environmental, social and economic spheres.

On September 25, 2015, 193 State Members of the United Nations adopted the Agenda for Sustainable Development until 2030. It proposes 17 Sustainable Development Goals that await

able at: http://erasmus-enter.org/files/r_1.3___best_ practices_of_pedagogical_education_for_engineering_teachers_(e-book).pdf

${ }^{3}$ Report of the World Summit on Sustainable Development (Johannesburg Summit), Johannesburg, South Africa, 26 August - 4 September 2002. Available at: https://sustainabledevelopment.un.org/milesstones/wssd 
joint efforts of the governments, private sector, and civil society to be achieved. This Agenda also considers education to be one of the leading influencers and drivers of a sustainable future [2; 3]. Professional actions of engineers influence directly the quality of life of the mankind; therefore, engineering education should play a crucial role in preparing students to become responsible engineers, to act following ethical, social, environmental standards, be responsible for the technical decisions they make. As a consequence, they should be able to cope with the challenges of sustainable development, to have specific attitudes and mindsets, knowledge and understanding, capabilities and skills and to work in such interdisciplinary or transdisciplinary settings.

Today, researchers are discussing the importance of the SD concept and its reflection in the realities of engineering education around the world [4-12].

Despite the recognition of the importance of reforming education systems for ensuring sustainable development, the efforts are not successful enough: insufficient and sometimes low level of knowledge and understanding in the field of sustainable development among decision-makers, educators, students, society at large. This is partly because pedagogical traditions are based on the transfer of existing knowledge, the reproduction of real connections and attitudes reflected in the public consciousness. That is why the ENTER Project consortium decided to take a step forward in the establishment of fundamentally new pedagogical and management tasks related to the formation of a sustainable development competence among engineering educators including the Sustainable Development course in the i-PET program.

The key factors ensuring the formation of required competencies within the educational process are the teaching and learning methods and conditions for their implementation (including the potential and qualification of faculty) and the specific university environments that support fostering of competences.
The analysis revealed the need to seriously change approaches to the organization of the traditional learning process. Certain stages and elements of SD will have to be implemented with the involvement of other stakeholders. Therefore, it is necessary to learn how to organize this component of the continuous learning process and extra-curricular activities in such a way that all target groups can apply and supplement knowledge and skills in the field of SD in the practice of their professional activity and everyday life. By including SD course in i-PET Program the ENTER project intends to provide all the support to deepen the knowledge and understanding how SD principles could be integrated into the engineering curricular to create a required core of academic staff with an open-minded view, SD mindset and readiness to implement changes focused on SD education at their HEIs.

\section{ENTER Sustainable}

\section{Development course description}

This course is designed within ENTER Consortium to help engineering educators to improve and develop their knowledge, understanding, skills, and abilities to teach students to recognize that engineers operate in a broad societal context and to take that context into account in their professional activity.

The main aim of the course is to develop the strategy to incorporate sustainable development principles into engineering education at large, including specific engineering courses.

The course is of 1 ECTS and could be delivered in different modes (face-to-face classes, blended or e-learning format only). At the same time, in any mode, the main focus is given to active learning methods allowing to increase the level of engagement in the learning process and ensure that engineering educators practice as much as possible such methods to be later widely implemented in their teaching routine with students. The list of teaching and learning methods proposed by course developers includes the following: project-based learning, forum theater, jigsaw, team-work, case study. 


\section{Specific Course Aims}

Develop SD mindsets, both on a professional and personal level. The most important mindsets in the domain of SD for engineering are critical thinking, holistic, systems thinking, entrepreneurial thinking, global mindset, cultural agility, and valuing learning over knowing. These are thinking modes that cannot be imitated by (networks of) intelligent machines and are unique for people i.e. social responsibility.

Design learning for buman needs. A major goal of higher education in the 21st century is to shift the learners' mind that learning is not just the acquisition of knowledge and skills, but a human quality and dispositions to cope with the uncertain world, complex life and a changing work environment, and to tackle the big challenges such as the UN SDG $[13 ; 14]$. It requires pedagogies that focus on gaining skills to learn and relearn, and the agility to change perspectives. It implies that the current faculty-centered curricula (anchored by existing physical spaces, staff resources, time-bound schedules) have to be transformed into (more) learner-centered and meaningful curricula with freedom of choice for the students.

Promoting impact-focused education. Impact-focused education accentuates experiential learning and that has meaning for students. It requires the accentuation of the relationship between engineering and society, where societal relevance should be the center of engineering. Increasingly curricula have to involve thematic studies across disciplines, human-centered and project-based learning with real-world connections and integrate work-based learning. Learning in randomness outside the academic cloister is the most effective teacher, but only when it is combined with student self-reflection and selfawareness.

Substantiate the necessity of the analysis through the prism of a green society. How education and green education program can help technologies more sustainable by counting and promoting green elements to evade ecological depletion and rehabilitated green technology to endow with the uncontaminated and unpolluted world for the next generation.
Nurture a culture of experimentation and innovation. Educational change has to be drawn on feedback, evidence and ideas from across the university hierarchy, and beyond the university. The educators should nurture an educational culture of continuous experimentation and innovation and be prepared to accept failure [15]. Be prepared for a future deregulating education environment (flexibility in rules and regulations), where the staff experimenting, and innovating education are important enablers of changing educational culture. It's not the institution that causes change, but it is the people.

Ensure scientific and professional integrity in the curricula. The role, responsibilities and ethics of engineers in society (solving human challenges and problems facing society) should be the focus of the SD engineering education.

Strengthening university-industry collaboration. Universities have to aggressively engage with industry to co-design curricula and course content, collaborate on applied research, and offer work-integrated learning [16]. Especially in this age of acceleration and digitalization, this requires a strong and enduring partnership between industry and academia.

Empower students to foster leadership and ethical behavior. The changing paradigms mean that engineering professionals have to be agile and resilient, and need skills that go beyond the 'traditional' engineering skills, thus the students must be trained with holistic thinking, the ability to work in interdisciplinary global teams and exert ethical leadership [17].

As the course syllabus is developed under the ENTER Project where special attention is paid to quality assurance and international accreditation and recognition, the outcome-based approach became the main pillar in the course design according to the EUR-ACE Framework Standards ${ }^{4}$ applied by international accreditation agencies to engineering education programs.

${ }^{4}$ EUR-ACE ${ }^{\circledR}$ Framework Standards and Guidelines (Electronic resource). Available at: https://www. enaee.eu/eur-ace-system/standards-and-guidelines/ 
Learning outcomes of the Sustainable Development course

\begin{tabular}{|l|l|}
\hline \multicolumn{1}{|c|}{$\begin{array}{c}\text { Group } \\
\text { of outcomes }\end{array}$} & \multicolumn{1}{c|}{ Outcome (number \& name) } \\
\hline $\begin{array}{l}\text { Knowledge and } \\
\text { Understanding }\end{array}$ & $\begin{array}{l}\text { O1 - Nurture mindsets and meanings in curricula; } \\
\text { O2 - Develop agile curricula with flexibility and freedom of choice for the } \\
\text { students; }\end{array}$ \\
\hline $\begin{array}{l}\text { Engineering } \\
\text { Analysis }\end{array}$ & $\begin{array}{l}\text { O3 - Substantiate the necessity of the analysis through the prism of green } \\
\text { technologies; }\end{array}$ \\
\hline $\begin{array}{l}\text { Engineering } \\
\text { Design }\end{array}$ & $\begin{array}{l}\text { O4 - Promote impact-focused education through interdisciplinary student- } \\
\text { centered projects with societal relevance (where societal relevance is the center } \\
\text { of engineering); }\end{array}$ \\
\hline Investigations & $\begin{array}{l}\text { Os - Nurture a culture of experimentation and innovation in education on } \\
\text { a limited scale, within a strategy for implementing more widely successful } \\
\text { innovations; }\end{array}$ \\
\hline $\begin{array}{l}\text { Engineering } \\
\text { Practice }\end{array}$ & $\begin{array}{l}\text { O6 - Integrate scientific and professional integrity and business ethics in } \\
\text { engineering curricula; } \\
\text { O7 - Intensify the collaboration with industrial partners and create more } \\
\text { opportunities for engineering practitioners in the classroom, engineering } \\
\text { projects, and internships at companies; }\end{array}$ \\
\hline $\begin{array}{l}\text { Transferable } \\
\text { Skills }\end{array}$ & $\begin{array}{l}\text { Os - Empower students (intra- and extracurricular) to foster leadership, } \\
\text { ethical behavior, deep collaboration, interdisciplinarity, and creativity. }\end{array}$ \\
\hline
\end{tabular}

The Sustainable Development course for engineering educators has 8 main outcomes grouped according to the EUR-ACE requirements as demonstrated in Table 1.

To achieve the above-stated outcomes the course developers propose the set of compulsory content units:

1. Introduction to Sustainable Development: 17 Sustainable Development Goals. This unit presents UN Sustainable Development Goals from an engineering education perspective. The 2030 Agenda encompasses 17 broad and interrelated Sustainable Development Goals (SDGs). The focus is made on the transformation of outcomes and results from engineering education and research into real life: notable impacts are fundamental for improving quality of life, increases in productivity and the associated growth in trade and access to education and work at regional, national, and global levels.

2. Engineering Curriculum and Education for Sustainable Development. Sustainable development is a complex concept which concerns a wide range of social, techno-economic and en- vironmental issues. Without addressing all these dimensions, the teaching course on sustainable development would not be complete. This unit intends to provide deep understating and develop competencies on how to integrate specific sustainability topics in courses and to have a separate course in sustainable development (where it is appropriate) to ensure those general SD aspects are included and that a team of faculty takes full responsibility for this. Complete lifecycle of products and systems projects are shown to be suitable tools for integrating teaching and learning of sustainable development.

3. Pedagogical strategies for learning sustainability in engineering education. This unit conceptualizes learning and education for sustainable development, analyzes the shift and transformation in the pedagogy used in Engineering Education Institutions needed to train engineers for sustainability. Learning strategies, techniques and activities dominate and their role to facilitate the shift to Education for Sustainable Development in Higher Education Institutions is analyzed. 
4. SDG Challenge as the capstone project. This unit is dedicated to developing guidelines on how to integrate sustainability aspects in students' engineering projects, finalizing by introducing SDG Challenge as the capstone project.

5. Extra-curricular activities to foster SD ethos. This unit is aimed at developing a specific university environment required to train engineers of the 21st century, focusing on the set of possible extra-curricular activities that needed to be organized and implemented to foster SD ethos.

As with any other syllabus, the Sustainable Development course provides a well-defined evaluation method to be implemented within the course. The assessment procedure consists of self-assessment realized in the form of an initial diagnosis of the SD ethos of enrolled students, not impacting the course evaluation. It is required to understand the initial competence level of engineering educators in the field of sustainable development for engineering education and allows them to make adequate changes in learning and teaching adapting to the specific needs and professional level of each group enrolled on the course.

The main teachers' assessment strategy incorporated in the course is the portfolio. It is a formative and summative type of assessment realized alongside the whole course duration in the form of individual project presentation of previously delivered portfolio reports. In the final task of this course, students will need to develop their strategy in integrating SD in a real course (given by them at their HEIs) to demonstrate how they have acquired the skills and knowledge to ensure SD ethos among engineering students.

An important element of this course is the portfolio evaluation. Four different moments are part of this evaluation: 1) Checklist that ensures that all necessary pieces are included; 2) Evaluate if the work is completed correctly (mechanics); 3) Evaluate if the work is complete (information); 4) Evaluate if the work is completed comprehensively (depth). Each area is marked on a scale of $1-5$. In the scale: $1=$ not at all; $2=$ somewhat; $3=$ mostly; $4=$ entirely, and $5=$ above expectations.

\section{Conclusions}

The process to incorporate sustainable development as one of the core courses into the certified training of engineering educators was presented.

The main aim of this course is to help educators to holistically integrate sustainable development principles into engineering education at large. With this approach, it is possible to nurture mindsets and meanings of sustainable development in the curricula as well as to develop an agile curriculum with flexibility and freedom of choice for the students.

This core course develops the necessity of the analysis through the prism of green technologies while promotes the impact-focused education through interdisciplinary student-centered projects with societal relevance.

While nurturing a culture of experimentation and innovation in education on a limited scale, within a strategy for implementing more widely successful innovations, the presented approach integrates scientific and professional integrity and business ethics into the engineering curricula.

The expected outcomes lead to an intensified collaboration with industrial partners and the creation of more opportunities for engineering practitioners in the classroom, engineering projects, and internships at companies.

Finally, with this course we expect the engineering educators are able to empower students to foster leadership, ethical behavior, social responsibility, deep collaboration, interdisciplinarity, and creativity.

\section{References}

1. Drake, S. \& Reid, J. (2018). Integrated Curriculum as an Effective Way to Teach 21st Century Capabilities. Asia Pacific Journal of Educational Research. No. 1, pp. 31-50.

2. Filho, W.L., Nesbit, S. (Eds). (2016). New Developments in Engineering Education for Sustainable Development. Switzerland: Springer. DOI: 10.1007/978-3-319-32933-8

3. Sivapalan, S., Clifford, M.J., Speight, S. (2016). Engineering Education for Sustainable Development: Using Online Learning to Support the New 
Paradigms. Australasian Journal of Engineering Education. Vol. 21, no. 2, pp. 61-73, DOI: 10.1080/22054952.2017.1307592

4. Wiek, A., Withycombe, L., Redman, C.L. (2011). Key Competencies in Sustainability: A Reference Framework for Academic Program Development. Sustainability Science. Vol. 6, no. 2, pp. 203-218. DOI: http://doi.org/10.1007/ s11625-011-0132-6

5. Fonseca, A., Macdonald, A., Dandy, E., Valenti, P. (2011). The State of Sustainability Reporting at Canadian Universities. International Journal of Sustainability in Higher Education. Vol. 12, no. 1, pp. 22-40. DOI: http://doi. org/10.1108/14676371111098285

6. Tejedor, G., Segalàs, J., Rosas-Casals, M. (2018). Transdisciplinarity in Higher Education for Sustainability: How Discourses Are Approached in Engineering Education. Journal of Cleaner Production. Vol. 175, pp. 29-37. DOI: https:// doi:10.1016/j.jclepro.2017.11.085

7. Kolmos, A., Hadgraft, R.G., Holgaard, J.E. (2016). Response Strategies for Curriculum Change in Engineering. International Journal of Technology and Design Education. Vol. 26, issue 3, pp. 391411. DOI: https:// doi:10.1007/s10798-015-9319-y

8. Dancz, C.L.A., Bilec, M.M., Landis, A.E. (2018). Active Experiential Sustainable Engineering Module for Engineering Education. Journal of Professional Issues in Engineering Education and Practice. Vol. 144, issue 1. DOI: https:// doi:10.1061/(ASCE)EI.1943-5541.0000345

9. Ketchman, K., Dancz, C.L.A., Burke, R.D., Parrish, K., Landis, A.E., Bilec, M.M. (2017). Sustainable Engineering Cognitive Outcomes: Examining Different Approaches for Curriculum Integration. Journal of Professional Issues in Engineering Education and Practice. Vol. 143, issue 3. DOI: https:// doi:10.1061/(ASCE)EI.19435541.0000324

10. McWhirter, N., Shealy, T. (2020). Case-Based Flipped Classroom Approach to Teach Sustainable Infrastructure and Decision-Making. International Journal of Construction Education and Research. Vol. 16, issue 1 pp. 3-23. DOI: https:// doi:10.1080/15578771.2018.1487892

11. Quadrado, J.C., Zaitseva, K.K. (2019). New Pedagogical Approaches to Induce Sustainable Development Goals. Vysshee obrazovanie v Rossii $=$ Higher Education in Russia. Vol. 28, no. 3, pp. 50-56. DOI: https://doi.org/10.31992/08693617-2019-28-3-50-56
12. Fischer, D., Jenssen, S., Tappeser, V. (2015) Getting an Empirical Hold of the Sustainable University: A Comparative Analysis of Evaluation Frameworks across 12 Contemporary Sustainability Assessment Tools. Assessment \& Evaluation in Higher Education. Vol. 40, no.6,pp.785-800.DOI:10.1080/02602938.2015. 1043234

13. (2015). World Federation of Engineering Organizations, WFEO Engineers for a Sustainable Post 2015, Congress on Engineering Education for Sustainable Development. Available at: http://www.wfeo.org/wp-content/uploads/declarations/Beirut_declaration_2015.pdf

14. Huntzinger, D.N., Hutchins, M.J., Gierke, J.S., Sutherland, J.W. (2007). Enabling Sustainable Thinking in Undergraduate Engineering Education. International Journal of Engineering Education. Vol. 23, no. 2, pp. 218-230.

15. Graham, R. (2018). The Global State of the Art in Engineering Education. Technical Report, Massachusetts Institute of Technology, Cambridge.

16. Henderikx, P., Jansen, D. (2018). The Changing Pedagogical Landscape: In Search of Patterns in Policies and Practices of New Modes of Teaching and Learning. European Association of Distance Teaching Universities (EADTU). Available at: https://eadtu.eu/documents/Publications/LLL/2018_-_The_Changing_Pedagogical_Landscape.pdf

17. Kamp, A. (2016). Engineering Education in the Rapidly Changing World: Rethinking the Vision for Higher Engineering Education. $2^{\text {nd }}$ rev. ed. Delft: TU Delft, Faculty of Aerospace Engineering. Available at: https://www.4tu.nl/ cee/en/publications/vision-engineering-education.pdf

Acknowledgments. ENTER project (EngineeriNg educaTors pEdagogical tRaining) is co-funded by the Erasmus + Programme of the European Union. This paper reflects the views only of the authors, and the European Commission cannot be held responsible for any use which may be made of the information contained therein.

The paper was submitted 31.03.20

Received after reworking 05.04.20

Accepted for publication 10.05.20 


\section{Принципы «устойчивого развития» \\ Аля преподавателя инженерных Аисциплин}

Квадраду Жозе Карлуш - А-р техн. наук, проф., вице-президент. E-mail: ipp@ipp.pt, Политехнический университет Порту, Португалия Aдpec: Rua Dr. Roberto Frias 4200-465, Porto, Portugal

Галиханов Мансур Флоридович - А-р техн. наук, проф., директор Института дополнительного профессионального образования. E-mail:mgalikhanov@yandex.ru Казанский национальный исследовательский технологический университет, Казань, Россия Адрес: 420015, ул. К. Маркса, 68 г. Казань, Российская Федерация

Зайцева Ксения Константиновна - канд. пед. наук, доцент. E-mail:kkzaitseva@gmail.com Томский политехнический университет, Томск, Россия Адрес: 634050, Проспект Менина, 30, г. Томск, Российская Федерация

Аннотация. В данной статье обоснован и детально представлен проиесс разработки и включения курса «Устойчивое развитие» в сертифичированную международную программу повышения квалификачии преподавателей инженерных дисииплин.

В рамках проекта программь ERASMUS + ENTER бъл создан консорииум для нарашивания потенииала инженерньх вузов путём усиления подготовки инженерньх педагогов с помощью применения инновачионных подходов инженерной педагогики. Одной из задач проекта является создание нового международного подхода к разработке многоуровневой модульной системы послевузовской профессиональной педагогической подготовки преподавателей инженерных дисииплин.

После тщуательного анализа рынка образовательньх услуг, требований вузов и потребностей преподавателей была разработана формальная программа обучения. Одним из основных курсов этой программы является модуль «Устойчивое развитие». Основная цель этого курса - помочь педагогам разработать стратегию интеграчии приниипов устойчивого развития в инженерное образование в челом.

Ключевые слова: преподаватели инженерных дисчиплин, повышение квалификачии, приниипь «устойчивого развития» В инженерном образовании, проект ENTER

Аля изитирования: Quadrado J.C., Galikhanov M.F., Zaitseva K.K. Sustainable Development Principles for the Engineering Educator // Высшее образование в России. 2020. Т. 29. № 6. C. 75-82.

DOI: https://doi.org/10.31992/0869-3617-2020-29-6-75-82

Статья поступила в редакиию 31.03.20

С доработки 05.04.20

Принята к публикачии 10.05.20 